\title{
How e-Government managers prioritise rival value positions: The efficiency imperative
}

\author{
Jeremy Rose $^{\mathrm{a}, \mathrm{b}}$, John Stouby Persson ${ }^{\mathrm{b}, *}$ and Lise Tordrup Heeager ${ }^{\mathrm{c}}$ \\ ${ }^{a}$ University of Skövde, Skövde, Sweden \\ ${ }^{\mathrm{b}}$ Aalborg University, Selma Lagerlöfsvej 300, Aalborg Ø, Denmark \\ cAarhus University, Bartholins Allè 10, Aarhus C, Denmark
}

\begin{abstract}
E-Government strategies, investments, project selection, and implementations are influenced by value positions deeply enshrined in the traditions of public administration, which are in turn reflected in the everyday discourse of public managers. We analyse value traditions in the public administration literature and their adaptation for e-Government and synthesise three prominent positions. Administrative efficiency focuses on cost-effectiveness logics highlighted by New Public Management thinking. Service improvement, derived from the tradition of public service, emphasises the provision of better services for citizens. Citizen engagement, with its roots in liberal democracy arguments, promotes responsiveness, consultation, collaboration and participation. A set of foundational values grounded in the deeply rooted bureaucratic tradition is also distinguished. A qualitative survey of Danish local authority managers' value positions shows a heavy bias towards administrative efficiency and an absence of concern for citizen engagement. The implications of this efficiency imperative are discussed.
\end{abstract}

Keywords: e-Government, value, local government, public administration, bureaucracy, New Public Management, IS management

\section{Introduction}

E-Government is a complex endeavour with many challenges, where public sector managers share responsibility for the selection, commissioning, implementation and benefits realisation of information technology projects. The scale of investment is large, covering diverse systems and many deployments against a backdrop of rapid technological evolution. The managerial challenge is correspondingly large, responding to expectations of politicians, employees, citizens and businesses. Prominent expensive failures [1] and large consultancy fees focus public attention on value-for-money and effective evaluation [2]3]. Realizing value becomes a prime consideration [4]; however many other concerns complicate the managerial task: privacy, data security, the digital divide, accountability, interoperability [5], architecture development, infrastructure and governance [6], project management [7], and utilization and take-up of services [8]. Early automation logics for e-Government (information technology (IT) should automate the work process), were replaced by the rhetoric of transformation [9]10]: government organisations should exhibit (radical) technology-driven change. In all complex endeavours, the expression of unifying goals and purposes is important: what are we trying to achieve and where are we heading? Public sector managers have a particular responsibility for articulating and pursuing policy objectives for digitalisation [11-14]. A way of expressing overall purpose, motivation and common goals

\footnotetext{
${ }^{*}$ Corresponding author: John Stouby Persson, Aalborg University, Selma Lagerlöfsvej 300, 9220 Aalborg Ø, Denmark. Tel.: +45 9940 8916; E-mail: john@cs.aau.dk.
} 
has recently emerged in the e-Government literature [15-17] through the study of values. Bannister and Connolly [17] suggest that 'public sector values are the foundation from which the idea of genuine transformation derives.' Understanding the value positions that are embedded in e-Government initiatives is a way of understanding underlying purpose and motivation for the field.

The value concept is widely used both in research and in public discourse about e-Government, with differing meanings. 'Value' and 'values' are semantically distinguished in ordinary speech. Value represents the 'worth, utility, or importance of an entity' [18] - that which is 'considered a good (worthy of striving after) without further justification or rational argument' [19]. Values may be described as 'normative characteristics or modes of behaviour that individuals, groups or organisations hold to be right, or at least better than other characteristics or modes of behaviour' [16]. We will use both variations as appropriate to our argument. Values may be personal (an 'internalised goal or ideal offered without further justification assumed to have universal agreement' [19]), or social: common values shared (or contested) by groups and communities, such as the e-Government managers in our study. Value is often expressed in economic or monetary terms, but in public administration a broader account of value [20|21] is often adopted, referring to:

- 'The value created by government through services, law, regulations and other actions' [22], or;

- 'The value or importance citizens attach to the outcome of government policies and their experience of public services' [23], or;

- 'Government's ability to deliver social and economic outcomes that correspond to citizens' expectations' [24].

This view includes value that cannot easily be defined, measured and translated into monetary units. Value studies serve many purposes, both summative and formative. Summative value studies form the basis for evaluating past initiatives; we adopt a formative view. Here values are the basis for future initiatives - 'broad guides to action' [19]. Our use of the term value aligns with Dewey's theory of valuation [25]: value(s) are associated with what is wanted (desires and intentions), with what is intended for the future (aims and purposes), and with how choices about ends and means are prioritised (prizing and appraisal). We will use Dewey's 'ends-in-view' formulation to signal this value perspective: assessments of intrinsic worth, leading to prioritizations of desirable behaviours, objectives and courses of action for the future. Thus in our conceptual language, value $\mathrm{x}$ will imply that, for a given group of people in a given time period, $x$ is considered of intrinsic worth such that it does not need to be argued or justified. Acting in a way consistent with $\mathrm{x}$, or adopting a course of action likely to lead to $\mathrm{x}$, or setting objectives promoting $\mathrm{x}$, is therefore desirable, and may be prioritised over other behaviours, courses of action or objectives. In this way we focus on overall purpose, motivation and common goals through the analysis of value.

The values debate flourishes in the public administration literature. Jørgensen and Bozeman [26] make an inventory of 72 public administration values which Rutgers [27] expands to over a hundred, commenting that the sheer number of possible relevant values is overwhelming. Researchers try to manage this complexity with classification, chronology, or dimensional difference (e.g. hard v soft values) [27]. A variety of different categorisation schemes are proposed [26|28-30] with rather little overlap or agreement. These studies emerged as an attempt to comprehensively map and categorize a distinct set of public sector values that serve to define a unified ethos for public service, as distinguished from the private sector ethos. However, more recent contributions understand values in public administration as ambiguous, hybrid and overlapping [31]. Values can be competing, clashing and contradictory [27]. Espoused values (those values that people claim to hold when asked about them) should be distinguished 
from values in-use (the values that actually lie behind their decision-making) [32], which makes empirical substantiation difficult. Validation is a general problem, both from the theoretical side, where the warrants, reasons and arguments for value categorisations are often missing [27], and from the empirical side, where there are conspicuously few attempts to match values proposed by theorists with systematic datasets collected from defined groups of research subjects.

E-government values (ends-in-view) deserve separate study because they are always connected to a particular form of implementation: information and communication technologies (ICT). Snellen [33] identifies three principal roles for ICT's in e-Government: supporting economy of implementation, supporting public service provision and supporting democracy:

'When we look at the deployment of ICTs in public administration, we see that originally ICT applications predominantly played a role in the enhancement of the internal effectiveness, efficiency, and economy of the executive functions of public administration ... Only later on did the improvement of the quality of public services to the citizens, as customers, clients, citizens, and subjects...came into focus ... More modest, however, are the applications ... which aim to support the involvement of citizens in democratic policy making' [33].

It follows that values relevant to e-Government are connected to assumptions about what ICTs are for, what they can do, how they can be integrated into administrative practice and what consequences they may produce, even if these assumptions remain unarticulated. Background understandings of this type produce cognitive framing effects - the technological frame [34] may be expected to modify the value landscape (the overall picture of available values - theoretical or empirical). Current e-Government value studies form a series of heterogeneous categorisation schemes [15|16|18|22- $-24|35|-42]$ predominantly targeting ex-post evaluation. They map many values, with many different theoretical inspirations and poor validation, echoing problems in the public administration literature described in the previous paragraph. They largely adopt the unified ethos perspective; there are few studies that recognise value rivalry. Nevertheless this stream of research has achieved a certain significance; Cordella and Bonina [43] promote public value as an important direction for e-Government research, and Bannister and Connolly [17] call for further study of underlying values to support this direction.

This study reported here investigates managerial value positions for the digitalisation effort in Denmark. We use the term value position to denote a group of values perceived to be largely complementary for a social group, be they theorists or managers. Though value positions express overall purpose, motivation and common goals through internally (largely) coherent and (largely) synergistic groupings of ends-in-view, we take the positions themselves to be (potentially) characterised by rivalry or competition. One reason for rivalry will be resource scarcity; there are many desirable ends-in-view but the means to implement them are strictly limited. Therefore some values, or value positions must be prioritised over others. A more serious reason will be incompatibility between values or positions: if managers interpret efficiency as achieving budget savings, then this may be incompatible with the service value (interpreted as providing a higher level of service to citizens). Thus the prioritisation of one value position may imply the neglect, or even denial of another. We identify value positions through analysis of value studies in the e-Government and public administration literatures, analysis of rival traditions in public administration theory, and empirically by collecting data from managers in local authorities in Denmark. We test the managers' prioritisation of value positions empirically.

Local authority (kommune) managers in Denmark enjoy significant influence over the progress of eGovernment. Danish local authorities are relatively de-centralized (commissioning and managing their 
own IT systems, for example), and are not merely an executive wing that carries out centrally determined policies. The 98 Danish kommunes employ approximately 500,000 people. In 2007, local authorities were re-organised into units of sufficient size to cope with increasing responsibility and task complexity during the consolidation of the welfare state. Local authorities are entrusted with running a large part of the Danish welfare state including primary education, day care for children, social welfare, and care of the elderly [44]. They enjoy much autonomy in how to organise them. Therefore their senior managers enjoy significant decision-making prerogatives. This authority makes managers salient stakeholders: key figures in the digitalization programme and expected to engage with value positions. We tackle the problem of distinguishing espoused values from values-in-action by analysing both the local authorities' strategy documents (espoused values), and making second order analysis of values-inaction from general conversations about e-Government priorities with senior managers. We address the research questions:

- How can rival value positions of public managers (understood as overall purpose, motivation and common goals for e-Government initiatives) be summarized?

- How do public sector managers prioritise value positions when they introduce new information and communication technologies (ICT)?

Our research strategy combines analysis of previous value categorisations, analysis of traditions from public administration, and empirical justification. In answering the first question, we first investigate recent e-Government value studies to understand which values are currently in focus (Section 2). We turn to the public administration literature to understand major rivalries in value positions, investigating three major trends in this literature in the last fifteen years (Section 3). We synthesize a framework for eGovernment values from these two investigations that captures structural rivalries in the positions that we expect public sector managers to work with (Section 4). We conduct a survey of local authority managers to answer the second question (using a combined strategy of qualitative and quantitative content analysis) in Section 5, that also allows us to deepen our understanding of the value framework (Section 6). We discuss the results and implications of both model and survey in Section 7.

\section{E-government values}

In this section we examine the e-Government value literature with two objectives. The first is to identify and group recurring values - these are often derived from the public administration debate. The second is to illustrate three research strategies that are used to work with them. The research strategies are

- Argument from value categorisations from the public administration literature;

- Derivation from theories or theoretical traditions;

- Empirical justification.

Bannister [16] identifies six categories of values for IS in public administration:

- Foundational: Positive cost benefit, cost savings/reduced headcount, avoided future costs, positive return on investment, positive net present value, risk reduction, greater staff efficiency, better control/reduction in fraud and waste, increase in capacity/throughput, mandatory;

- Policy formulation: Better management information, support for decisions;

- Democratic: Citizen access to information, transparency, flexibility, policy alignment;

- Service: Good service to the customer, good service to the citizen, meeting public demands; 
Table 1

Bureaucratic and new public management values [15]

\begin{tabular}{ll}
\hline Traditional bureaucracy values & New Public Management values \\
\hline - Legitimacy & - Customer orientation \\
- Rule of Law & - Decentralization \\
- Application of detailed rules & - Mission and goal orientation \\
- Efficiency & - Improved accountability for results \\
- Effectiveness & - Improved responsibility to address client needs \\
- Equality & - Focus on cost-efficiency \\
- Legality & - Focus on productivity \\
- Impartiality & - Shift from idea of spending to earning \\
- Objectivity & - Introducing market mechanisms, competition, incentivisation \\
- Transparency & - Introducing a higher degree of flexibility and discretion \\
- Accountability & - Empowerment of street-level bureaucrats \\
- Specialization & - Deregulation as reform strategy \\
- Citizen as subordinate to the administration & - Pushing control from hierarchy of bureaucracies to community \\
& - Preventive and proactive approach rather than reactive and curing \\
& - Separating policy formulation from implementation \\
\hline
\end{tabular}

- Internal: Improved staff morale, improved internal communications, improved ability to attract staff, better staff retention, more motivated staff, empowering staff, greater staff creativity;

- External: Being abreast of the private sector, having a good public image, being abreast of other administrations, matching other external benchmarks [16].

In Bannister and Connolly [17], recognisably similar values are reorganised into three categories: duty-oriented, service-oriented and socially-oriented. The research strategy is an argument from previous value categories: some competing categories from the public administration literature are examined and new categories are proposed with (literature based) reasoning devised by the authors. This research strategy offers neither a strong theoretical nor empirical warrant. Persson and Goldkuhl [15] derive a core set of values by contrasting historical traditions in the public administration literature: traditional bureaucracy from the work of Weber [45], and New Public Management (Table 1). The research approach anchors its argument theoretically by deriving values from well-understood public administration traditions. However they fail to identify potential tensions and contradictions (for instance between accounts of citizen as client and customer, or the rule of law and deregulation). Moreover their classification ignores trends in public administration over the last fifteen years. A further problem is the introduction of elements that many might understand as partisan objectives (deregulation, market mechanisms) rather than values. They also demonstrate the third research strategy: they test their conceptual organisations against empirical data and ground their account of e-Government values (as a synthesis of the two value sets) in a case study. Other e-Government researchers use variations of these strategies to focus on the service dimension [22 37/42] or the internal managerial dimension [18]. Kim and Kim [38] add organisational learning and information security considerations, and various ideas of social and political value as complements to economic values appear and reappear [35[39]. Yu [42] incorporates elements from the Layne and Lee [46] stages of e-Government model, including vertical and horizontal integration as desirable values. Scott et al. [23] add a citizen perspective, pointing out that citizens' values do not necessarily correspond with administrational values. Bonina and Cordella [24] summarize parts of the discussion by identifying two categories of values: managerial public values (such as efficiency, effectiveness and performance of tasks) and democratic public values (which they characterize as equity, fairness and honesty). Table 2 summarizes recurring groupings of values discussed in the e-Government literature. 
Table 2

Groupings of recurring values in the e-Government value literature, derived from Rose and Persson [47]

\begin{tabular}{cl}
\hline & Value groupings \\
\hline a & Honesty, fairness, impartiality, equality before the law, legality, objectivity, professionalism \\
b & Legitimacy, trustworthiness, openness, transparency \\
c & Robustness, reliability, accountability, security \\
d & Efficiency, effectiveness, economy, productivity, performance \\
e & Public service, citizen (or customer) orientation, service level, service quality \\
f & Responsiveness, consultation, collaboration, participation \\
\hline
\end{tabular}

\section{Rival value positions: Three public administration traditions}

In this section, we outline three traditions that can be aligned with the historical development of public administration praxis and analyse the value positions that they embody. The objective is to understand how the e-Government values identified in the previous section fit with broader value positions in the public administration literature. Civil service traditions associated with Weber's account of bureaucracy became gradually discredited ('bankrupt' [48]) in the 80's and 90's, at least in the Anglo-Saxon democracies (USA, Great Britain, New Zealand, Australia, Canada), and overtaken by practices associated with New Public Management. However, some aspects of New Public Management provoked strong reactions in their turn. One reaction was the reaffirmation of bureaucratic values: a restatement of enduring public administration values summarized in Goodsell's [49] 'The Case for Bureaucracy'. The other reaction described here is a positive affirmation of both public service and liberal democratic ideals summarized in Denhardt and Denhardt's [50] 'The New Public Service' that is associated with Moore's [20] account of public value.

\subsection{Old public administration values (Weberian bureaucracy)}

Weber [45] describes how economic purposive rationality (capitalism) replaces religion as the driving force of society, bringing with it the superior organisational form of bureaucracy. Bureaucracy is characterised by six principles:

- Official jurisdictional areas are fixed and ordered by rules, laws, and regulations;

- Structural hierarchy with superior and subordinate relationships;

- Written files as the foundation for management of the office;

- Qualification for office is based on expertise and training;

- Professionalization - full time employment of personnel who are compensated and rise through a career structure;

- Administration follows stable rules that can be learned.

Bureaucracy is underpinned by belief in legitimate authority expressed in patterns of normative rules, and the right of those elevated to authority to issue commands. Rational-legal authority organised in the bureaucratic state apparatus forms the classical civic service. The bureaucratic organization exhibits 'purely technical superiority over any other form of organization' [45]: 'optimized precision, speed, unambiguity, knowledge of the files, continuity, discretion, unity, strict subordination, reduction of friction and of material and personal costs.' Bureaucracy also promotes objectivity (casework according to calculable rules without regard for individual status or position) in administration, and thus fairness: equality before the law. Dealing objectively with complexity and specialization requires a detached expert, a trained professional official who both can understand the regulations, and administer them in an equitable way. Weber described bureaucracy but did not idealize it; he recognized many problems 
inherent in state bureaucracies. They tend to expand, and to preserve and extend their own power, exercising a form of domination that turns citizens into clients. They do not necessarily seek or promote the public good, especially where it might conflict with the underlying regulative system. Bureaucracy is naturally secretive, locating power in groups of inaccessible high-status officials, and places the authority of officialdom above public opinion. Nevertheless traditional bureaucracy (termed the 'old public administration' by Denhardt and Denhardt [51]) affirms values drawn from Weber such as due process and the rule of law, fairness, objectivity and impartiality, accountability through hierarchy, professionalism, legitimacy, trustworthiness, and efficiency. These values (reflected in value groupings a, b and c of Table 2) continue to form the foundational bedrock of modern public administration.

\subsection{New Public Management values}

The starting point for New Public Management was a perception of the Old Public Administration as

'Formal bureaucracies plagued with excessive rules, bound by rigid budgeting and personnel systems, and preoccupied with control. These traditional bureaucracies are described as ignoring citizens, shunning innovation, and serving their own needs' [51].

The old public administration is seen as wasteful, static, overstaffed and unresponsive (the modern vernacular usage of the word 'bureaucratic') - in short 'broken' [52]. New Public Management's response to this perception is derived from management practice from the private sector. Boston [53] characterises the central doctrines of New Public Management as

[an] emphasis on management rather than policy; ... a reliance on quantifiable output measures and performance targets; ... the development of new reporting, monitoring, and accountability mechanisms; the disaggregation of large bureaucratic structures ...; a preference for private ownership, contracting out, ... private sector management practices such as ... the development of corporate plans (and) performance agreements, the introduction of performance-linked remuneration systems; a general preference for monetary incentives rather than non-monetary incentives ...; a stress on cost-cutting, efficiency, and cutback management [53].

Much public attention was captured by the Reinventing Government movement [54|55]:

- Catalytic government: Steering rather than rowing (focusing on leadership rather than service delivery);

- Community owned government: Empowering rather than serving (transferring power to citizens through public choice);

- Competitive government: Injecting competition into service delivery (relying on market mechanisms to drive efficiency);

- Mission-driven government: Transforming rule-driven bureaucracies (focus on proactive improvement of communities rather than passive administration of law);

- Results-oriented government: Funding outcomes, not inputs (measuring results, rather than distributing budgets);

- Customer driven government: Meeting the needs of customers, not the bureaucracy (developing a citizen-centric focus);

- Enterprising government: Earning rather than spending (focus on entrepreneurial government);

- Anticipatory government: Preventing rather than curing (antidote to passive and reactive governmental style); 
- Decentralized government: Moving from hierarchy to participation and teamwork (reorganization of traditional bureaucratic organisational forms);

- Market-oriented government: Leveraging change through the market (change from social program enactors to entrepreneurial brokers, facilitators and seed capitalists manipulating the market) [55].

The Reinventing Government movement emphasized entrepreneurial government promoting competition between service providers by privatising services, and having (citizen) customers exercise choices governed by individual economic interest. Government's role is to catalyse public, private and, voluntary sectors through market forces to solve their communities' problems proactively, rather than to enforce the law or to (necessarily) provide services themselves. They are thus motivated by their goals and missions, not by rules and regulations. Government institutions should actively seek ways of increasing their revenue (not just administer their budgets effectively), and monitor performance outcomes. Government officials become entrepreneurial managers charged with galvanising bureaucracies into action in the same way that managers in industry (supposedly) can. In summary, the Reinventing Government movement prefers 'market mechanisms to bureaucratic mechanisms' [54].

The Reinventing Government movement began to attract criticism almost as soon as it gained political momentum, with one reaction focused on defending bureaucratic values. Moore [56] deplores the 'precedence of economically-based values over legally-based values.' Entrepreneurial independence for government officials risks undermining the rule of law, and accountability for actions up through the hierarchy to the head of state. Privatisation tends to erode bureaucratic values (impartiality, fairness, objectivity), replacing them with commercial values. Changes to administrative practices designed to minimise red tape by short-circuiting rule-based practice eventually undermine the executive branch's function (to execute the law as decided by elected representatives of the people), and thus fundamental democratic values. The 'business is best' assumption is dismissed by Goodsell [49] as prejudice; he finds little empirical evidence for the proposition that businesses consistently perform better than government. Basing public policy on the cumulative market effect of self-interested service consumers requires an act of faith: that the market can come to determine the public good better than elected lawmakers and professional executors. Treating citizens as customers risks creating inequalities based on ability to pay. It tends to undermine the public welfare function of government and ignores the role of the citizen in deliberative democracy. Public administrators should primarily respond to the political process and their many constituents and stakeholders - not to the market. Moreover the single-mindedness, tenacity and willingness to bend the rules associated with the entrepreneurial spirit are not necessarily an asset in government [57].

New Public Management values, however, remain a defining part of modern public administration, though many of the goals of (particularly) the Reinventing Government movement today appear partisan, political, or ideological. Objectives identified by Hood [29] - value for money, professional leadership, citizen-centricity, performance review, a role for the market - are no longer understood as incompatible with traditional bureaucratic values, but as complementary to them. New Public Management can in particular be associated with the values of efficiency, effectiveness, economy, productivity, performance, customer orientation, and a concern for effective customer-facing service provision (reflected in value groups d and e in Table 2).

\subsection{New public service values}

New Public Service values (a reaction to New Public Management) are located in traditions of public service, public value management, and the idea of liberal or deliberative democracy. 
In the public service tradition, government officials respond to a higher calling to serve the public interest, and to develop public value. Weber argued that, as rationality replaced religion as the driving force of society, a religious calling as a motivation for action was replaced by commitment (service) to the bureaucracy, ultimately to the state. The ethos of office [58] (the vocation of public service based on an ethical commitment to act in the public good) allows government to act forcefully, morally and accountably, distinguishing government from politics or business. However, determining and delivering the public good is not a simple task. If the democratic process resulted in politicians delivering perfectly formed policies devoid of special interest, short-sightedness, the avoidance of painful trade-offs, or corruption (argues Moore [20|21]) then the public management task would be limited to efficient implementation - a classical separation of policy formulation and implementation. An alternative conception of public value might be grounded in the satisfaction of citizens with the services that public institutions deliver. Certainly the analytical tools provided by NPM (such as cost-benefit analysis, cost effectiveness analysis, program evaluation) can make a major contribution to targeting and measuring public value. In practice, an important part of the public manager's role in delivering public value will be to strengthen the political mandates that they are required to work with. Policies must 'reflect the proper interest and concerns of the citizens; the story about the value to be produced must be rooted in accurate reasoning and real experience; and the real operating experience of the organisation must be made available' Moore [21]. In the liberal and deliberative democracy traditions, the public interest is defined and re-defined through dialogue between citizens, politicians, and public servants. Here citizenship entails more than consuming services; it also implies the ability to influence decision-making and policy development, and active involvement in political life. Such accommodations are achieved through discourse, negotiation, the building of shared agendas, and consensus between citizens and government. These concerns also surface in the management of networked inter-organizational organisations driven by trust and relationships, characterised as New Public Governance by Osbourne [59]. In a liberal democracy, the institutions of government respond to shared views of the public interest, whilst respecting fundamental liberties and working to 'block efforts by narrow factions to coerce ... the public for reasons not warranted by the public interest' [60]. Thus, public servants have a special responsibility to listen to the voices of citizens, be responsive to what is said, find and articulate a general or common interest, and to cause government to pursue that interest [61].

Denhardt and Denhardt [50] respond to the rhetoric of the Reinventing Government movement in defining an alternative set of values, which they term the New Public Service:

- Serve Citizens, Not Customers: Focus on building relationships of trust and collaboration with citizens;

- Seek the Public Interest: Building a collective, shared notion of the public interest - the creation of shared interests and shared responsibility;

- Value Citizenship over Entrepreneurship: Public servants and citizens committed to meaningful contributions - not entrepreneurial managers;

- Think Strategically, Act Democratically: Policies and programs meeting public needs through collective efforts and collaborative processes;

- Recognize that Accountability isn't Simple: Public servants attentive to statutory and constitutional law, community values, political norms, professional standards, and citizen interests as well as the market;

- Serve Rather than Steer: Value-based leadership to help citizens articulate and meet shared interests;

- Value People, Not Just Productivity: Success dependent on processes of collaboration and shared leadership based on respect for people [50]. 
Table 3

Rivalry in values between Old Public Administration (OPA), New Public Management (NPM), and New Public Service (NPS) e-Government value groupings (Table 2) Rivalry among the public administration traditions

a Honesty, fairness, impartiality, equality before the law, legality, objectivity, professionalism

b Legitimacy, trustworthiness, openness, transparency

c Robustness, reliability, accountability, security

Non-contentious: accepted by all three (though only the professionalism value is targeted by NPM)

Non-contentious: accepted by all three

Non-contentious: accepted by all three

d Efficiency, effectiveness, economy, productivity, performance

e Public service, citizen (or customer) orientation, service level, service quality

f Responsiveness, consultation, collaboration, participation

Contentious: accepted by OPA, prioritised by NPM, downplayed by NPS (however efficiency in pursuit of policy implementation non-contentious across all traditions)

Contentious: only partially recognised by OPA, given a particular market orientation by NPM, prioritised by NPS

Contentious: not recognised by OPA, NPM (except in terms of responding to market preferences of customers), prioritised by NPS

They are critical of the sparse attention to democratic citizenship evident in the Reinventing Government movement and argue for the 'reaffirmation of democratic values, citizenship and service in the public interest' and that 'public servants do not deliver customer service - they deliver democracy'. Government 'shouldn't be run like a business, it should be run like a democracy' [50].

New Public Service values are derived from the traditions of public service and liberal democracy, and include: dialogue, deliberation, consultation, consensus building, collaboration, service and commitment to the public interest, shared leadership, respect for citizens, and participatory policymaking. These align with the values of responsiveness, consultation, collaboration, participation, and with the citizen orientation and service values identified in the e-Government value literature (Table 2, value groupings $\mathrm{e}$ and $\mathrm{f})$.

Table 3 outlines the major rivalries between values (from Table 2) exposed by the different agendas of the public administration traditions. Three groupings of e-government values ( $d$, e, and $f$ in Table 3 ) reflect rivalry between public administration traditions while the three remaining groupings $(\mathrm{a}, \mathrm{b}, \mathrm{c}$ in Table 3) less contentious. In the following section, we propose a model of rival value positions based on the analysis of e-Government values (Section 2) and public administration traditions (Section 3).

\section{Rival value positions for e-Government}

In this section, having offered an analysis of commonly discussed e-Government values through the lens of theoretical traditions in public administration, we re-focus on the task in hand: the study of purpose, motivation and common goals for e-Government through managerial value positions. Since e-Government always concerns the deployment and exploitation of information technologies, we study basic motivations for selecting, commissioning and implementing IT in the public sector and the consequent realisation of benefits. The underlying shape of the value model in this section is consistent with a comprehensive discussion of public administration ethics by Dobel [28]. He defines a common set of formative or foundational values for public administration (derived from traditional bureaucracy). These generally agreed values are complemented by values primarily associated with New Public Management, and values primarily associated with liberal democracy. We expand this idea by identifying three rival value positions consistent with Snellen's [33] description of the role of IT in e-Government (supporting economy of implementation, supporting public service provision, and supporting democracy). Rivalry occurs either because of scarcity of resources for pursuing value positions, or because of perceived incompatibilities between values. The three rival positions are underpinned by a set of more generally agreed foundational values. 


\subsection{Administrative efficiency}

Administrative efficiency characterises the drive to exploit the automation effects of IT in government. It focuses on the search for value for money expressed by the values: efficiency, effectiveness, economy, productivity, and performance. Bannister [16] deconstructs these as: positive cost benefit, cost savings/reduced headcount, avoided future costs, positive return on investment, positive net present value, risk reduction, greater staff efficiency, better control/reduction in fraud and waste, and increase in capacity/throughput. Though not incompatible with traditional bureaucratic values, administrative efficiency reflects the enduring impact of the values of cost efficiency and productivity at the centre of the managerial model favoured by New Public Management. It may also incorporate New Public Management values of performance assessment and accountability through results, and some degree of market orientation, competition and incentivisation facilitated by IT. Internal e-Government initiatives pursue these objectives with database, tracing and tracking, desk-top and decision support technologies [33], amongst many others. The underlying cognitive framing of ICT focuses on automation: IT systems streamline administration allowing greater throughput with less manpower, with improved management information as a beneficial side-effect.

\subsection{Service improvement}

Service improvement focuses on the ability of ICTs to improve the experience of government for citizens, through for instance better access, avoiding travel, shorter response times, better access to information, online applications and transactions, special provision for disability, language support for minorities, online advice, automated benefits payment, and cost savings for citizens. The underlying values (public service, citizen orientation, service level, service quality) are derived from public service ideals articulated by Denhardt and Denhardt [50] and from the customer orientation of New Public Management. Bannister and Connolly [17] also identify this set of values as important for the evaluation of IT impacts. ICTs offer many opportunities to provide better services to the public through the development of e-services supported by the internet, and increasingly, mobile services. The cognitive framing of ICT is as a service enabler. The provision of these automated service developments is costly, at least in terms of initial technology investments, and therefore potentially in competition with investments aimed at internal administrative efficiency. The online provision of a service in an attempt to reduce personnel costs incurred in over the counter service delivery does not automatically constitute an improved service to the public (especially if the citizen values a face-to-face encounter) but is part of a long tradition of the automation of manual tasks through ICT.

\subsection{Citizen engagement}

Citizen engagement relies on the power of ICTs to connect government with citizens. It combines ideals of citizen-centricity and community empowerment from New Public Management with the liberal democracy ideals of the New Public Service in the values: responsiveness, consultation, collaboration, participation. Bannister [16] understands the democratic values as citizen access to information, transparency and flexibility, and further understands policy-making as an internal administrative concern. Liberal democracy advocates would go further and focus on dialogue, deliberation, responsiveness, consultation, participation, openness, consensus building, collaboration, shared leadership, and participatory policymaking. Bannister and Connolly [17] summarise some of these aspirations as 'facilitating the democratic will.' Citizen engagement is, however not only a democratic ideal. Online services have 


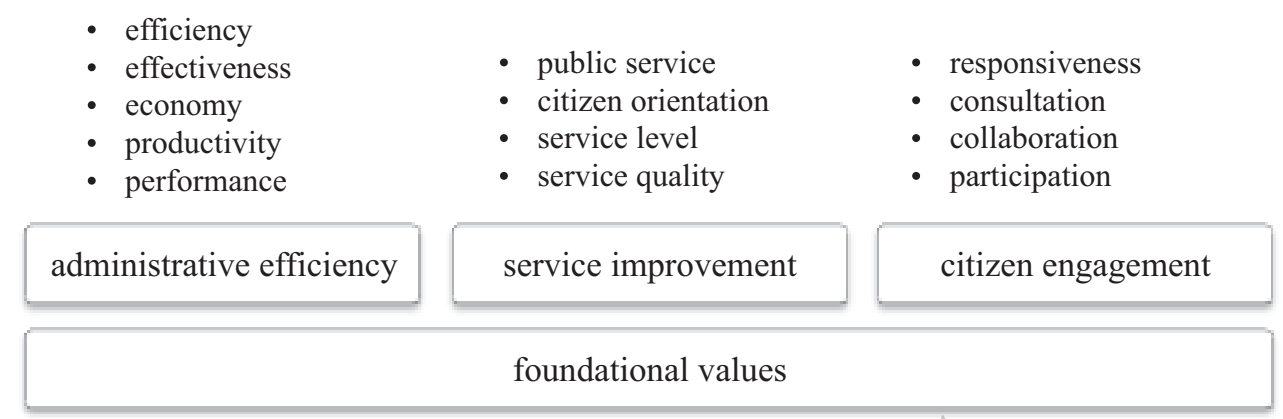

honesty, fairness, impartiality, equality before the law, legality, objectivity, professionalism, legitimacy, trustworthiness, openness, transparency, robustness, reliability, accountability, security

Fig. 1. Rival value positions for e-Government: administrative efficiency, service improvement, citizen engagement.

little efficiency impact if citizens do not engage and use them. Engagement should not be confused with information provision, customer feedback, or transparency. Where information and transparency provide the basis for understanding for informed citizen participation, citizen engagement is dependent upon the administration's resolve to determine the public interest and to act upon it. ICT is cognitively framed as a communication platform. Citizen engagement is primarily facilitated by the wave of web 2.0 technologies, and is also costly to implement - therefore easily in competition with an efficiency ideal.

\subsection{Foundational values}

Whereas the three value positions (administrative efficiency, service improvement, citizen engagement) can represent the motivation for major new initiatives in e-Government, they are dependent upon the maintenance of many other common values, which can be associated with traditional bureaucratic virtues. We borrow the term foundational values for these. Foundational values reflect the traditional bureaucratic values identified earlier: honesty, fairness, impartiality, equality before the law, legality, objectivity, professionalism, legitimacy, trustworthiness, openness, transparency, robustness, reliability, accountability, and security. Dobel [28] connects these values with traditional bureaucratic responsibilities such as framing decisions by law and authorized policy, demanding good information for decisions, maintaining accurate durable records, building durable and competent institutional capacity and impartially serving citizens. We have characterised these values as less contentious and note that they appear relatively consistently through the many competing traditions in the public administration literature and e-government value studies. These foundational values motivate the backbone of government, which is now heavily dependent on its ICT systems for its everyday function. A cognitive framing for ICT here might be as infrastructure: the digital public record, combined with the embedding of much practice in operational systems.

Figure 1 summarizes the e-Government value positions, allocating the values identified in the earlier e-Government studies in Table 2, and combining them with value positions anchored in the public administration literature (Table 3).

The model delineates potential rivalries in value positions amongst public sector managers. Prioritising one position implies reduced focus, or fewer resources for another position. Foundational (non contentious) values (Table 2, groupings a-c) are built into e-Government projects focusing on enhancing infrastructure, robustness and reliability in maintaining the administrative record, and in all other 
projects in as much as they observe the law, provide equivalent information about citizens to administrators, protect citizens' data security and so on. Administrative efficiency values (Table 2, grouping d) are embodied in initiatives with (for example) enterprise resource planning systems, customer relationship management systems, document management systems, administrative systems supporting case handling in the various administrative areas, basic provision of information to citizens through web-sites, e-procurement (primarily database-based). Service improvement values (Table 2, grouping e) manifest themselves primarily in web and mobile services, one stop shop, 24/7 projects, though these can also support administrative efficiency. Examples of citizen engagement (Table 2, grouping f) projects are email, discussion forums, e-voting, online political discourse, online decision making, e-consultation, e-hearings and e-petitioning [62[63].

\section{Empirical research method}

The overall research strategy combines the three commonly used research strategies in this area identified in Section 2:

- Argument from value categorisations (here from the e-Government literature rather than the public administration literature) in Section 2;

- Derivation from theories or theoretical traditions in the public administration literature (Section 3);

- Empirical justification (to follow in Section 6).

The empirical work is a pre-structured qualitative survey [64], taking the form of opinion research, where the objective is 'to gather data on attitudes, opinions, impressions, and beliefs of human subjects' [65]. Qualitative surveys aim at determining the 'diversity of some topic of interest within a given population' and establish 'the meaningful variation (relevant dimensions and values) within that population' [64]. The population here consists of Danish local authority managers. In a pre-structured survey some main topics, dimensions and categories are defined beforehand (in our case through theoretical argumentation) which are explored by means of semi-structured interviews and document study. The survey sample is chosen for diversity (coverage of the categories) and saturation (coverage of population diversity). We employ downward coding to specify diversity within the pre-defined categories, moving towards a lower level of abstraction [64].

\subsection{Data collection}

We collected data from 10 of Denmark's 98 local authorities (kommunes), covering all of the major regions. We aimed at diversity, including small (population 40,000) and large $(315,000)$, rich and poor, rural and urban and with both mature and immature e-Government provision. Semi-structured interviews were conducted in 2009 with the chief executive officer (CEO) the chief information officer (CIO), and the citizen service manager (CSM): in total, 30 interviews of 1-11/2 hours (see Appendix 1). In addition, we collected the local authorities' IT strategy documents - the formal declaration of the purposes and goals of the managers in the local authorities, in which their values are taken to be embedded. Thus, the IT strategy documents provide insights on espoused values while the interviews with managers provide insights on values-in-action [32]. The interview protocols open-ended questions focused on their management practices, challenges, priorities, goals, organization, decisions, context, and strategies related to IT and digitalization in their municipality. 
Table 4

The coding steps

\begin{tabular}{|c|c|c|c|c|}
\hline & Step & Activity & Actor(s) & Outcome \\
\hline 1. & Pilot coding & $\begin{array}{l}\text { Coding of three value positions, four data } \\
\text { sources }\end{array}$ & Second author & 82 value codes and text examples \\
\hline 2. & $\begin{array}{l}\text { Evaluation of } \\
\text { pilot coding }\end{array}$ & $\begin{array}{l}\text { Discussion of coding accuracy in relation to } \\
\text { the theoretical background }\end{array}$ & All three authors & $\begin{array}{l}8 \text { changes in the coding indicating a } \\
90 \% \text { agreement rate. }\end{array}$ \\
\hline 3. & $\begin{array}{l}\text { Coding of entire } \\
\text { dataset }\end{array}$ & $\begin{array}{l}\text { Each person codes half of the dataset em- } \\
\text { ploying the three value positions while con- } \\
\text { currently coding in vivo }\end{array}$ & $\begin{array}{l}\text { Second and third } \\
\text { author }\end{array}$ & 380 value codes, 680 in vivo codes. \\
\hline & $\begin{array}{l}\text { Coding accuracy } \\
\text { check }\end{array}$ & $\begin{array}{l}\text { Checked each other's coding, sampling all } \\
\text { local authorities and the four different data } \\
\text { sources }\end{array}$ & $\begin{array}{l}\text { Second and third } \\
\text { author }\end{array}$ & $\begin{array}{l}5 \text { changes in the coding sample in- } \\
\text { dicating a } 92 \% \text { agreement rate. }\end{array}$ \\
\hline 5 . & $\begin{array}{l}\text { Categorizing in } \\
\text { vivo codes }\end{array}$ & Comparative analysis of the in-vivo coding & $\begin{array}{l}\text { First and second } \\
\text { author }\end{array}$ & $\begin{array}{l}100 \text { categories with a distribution of } \\
42,33 \text {, and } 25 \text { across the three value } \\
\text { positions }\end{array}$ \\
\hline
\end{tabular}

\subsection{Data analysis}

We conducted a content analysis of the transcribed interviews and IT strategy documents, which provide 'a relatively systematically and comprehensive summary or overview of the dataset as a whole' [66]. Content analysis involves observing repeating themes and categorizing them using a coding system elicited in a grounded way (built up from the data) or from some external source (in this case theoretical value constructs). While the respective frequency of category occurrence may imply some form of significance, simple counting methods divorce occurrences from their context and much information relevant to the interpretation of the material is lost. We address this limitation by adding qualitative content analysis [66] - a form of discourse analysis where the thematic categories are studied in their location in the source text, where the addition of context can help to identify additional relevant factors. Since we also seek to analyse tensions and contradictions between values, we focus on the competing value positions, rather than the less contentious foundational values.

We used the analysis software NVivo 8 for the code-based analysis, distinguishing between theoretical constructs (e-Government value positions Fig. 1) and in vivo codes 'based on the language of the research participants' [67]. A coding granularity of one or more coherent statements was chosen to make the coded text more self-explanatory when extracted from context. The in vivo coding was of specific practitioner concepts and claims within the coherent statement coded with a value position. This in vivo coding was conducted in parallel with the coding of the theoretical value constructs as noted in the third of the five analytical steps summarized in Table 4. The theoretical coding ensures systematic exposure of all items of relevance, allowing for quasi-statistics designed to permit judgments about the frequency and range of e-Government value positions [67]. The (downward) in vivo coding allows conceptual elaboration of the value positions, grounded in the concepts used in the data sources.

Data collection includes a number of steps designed to prevent bias in collecting data and interpreting results. About a dozen interviewers contributed, most of whom were not involved in the analysis work, and the coding steps include a number of quality and reliability checks.

\subsection{Theory building}

The research generates a mid-range [68] descriptive theory of type 1 [69], providing a 'lens for viewing or explaining the world' - in particular for 'understanding the complex world of lived experience 
Table 5

Value position examples from each of the four data sources

\begin{tabular}{|c|c|c|c|c|}
\hline & Municipal CIO & Municipal CEO & Citizen service manager & IT strategy document \\
\hline $\begin{array}{l}\text { Administrative } \\
\text { efficiency }\end{array}$ & $\begin{array}{l}\text { "project management is } \\
\text { based on ... the develop- } \\
\text { ment of business cases } \\
\ldots \text { you have to be very } \\
\text { specific on the finan- } \\
\text { cial benefits..." (Inter- } \\
\text { view 16) }\end{array}$ & $\begin{array}{l}\text { "our ambition ... is } \\
\text { to maintain the same } \\
\text { level of service for the } \\
\text { same money but with } \\
\text { fewer employees..." } \\
\text { (Interview 17) }\end{array}$ & $\begin{array}{l}\text { "I try to explain our } \\
\text { politicians that if they } \\
\text { want digitalization and } \\
\text { efficiency, we need to } \\
\text { close local citizen service } \\
\text { centres ..." (Interview 6) }\end{array}$ & $\begin{array}{l}\text { "We use IT to develop and } \\
\text { streamline our tasks and } \\
\text { decision processes." } \\
\text { (Gentofte, strategy) }\end{array}$ \\
\hline $\begin{array}{l}\text { Service } \\
\text { improvement }\end{array}$ & $\begin{array}{l}\text { "IT is interesting to } \\
\text { politicians if you can } \\
\text { improve some of the } \\
\text { services to citizens." } \\
\text { (Interview 1) }\end{array}$ & $\begin{array}{l}\text { "our overall goal is to use } \\
\text { IT for propagating ser- } \\
\text { vice to the citizens ..." } \\
\text { (Interview 11) }\end{array}$ & $\begin{array}{l}\text { "the information is } \\
\text { pushed out ..... making } \\
\text { us more proactive ... so } \\
\text { you don't have to wait in } \\
\text { a line." (Interview 18) }\end{array}$ & $\begin{array}{l}\text { "citizens and companies are } \\
\text { offered access to user } \\
\text { friendly IT ... supporting } \\
\text { their needs for information } \\
\text { search, exchange, and case } \\
\text { management ... indepen- } \\
\text { dent of time and place." } \\
\text { (Aarhus, strategy) }\end{array}$ \\
\hline $\begin{array}{l}\text { Citizen } \\
\text { engagement }\end{array}$ & $\begin{array}{l}\text { "we are changing to a } \\
\text { digital society ..... dig- } \\
\text { italization can bring us } \\
\text { closer to the citizen ..." } \\
\text { (Interview } 25 \text { ) }\end{array}$ & $\begin{array}{l}\text { "we need to focus on our } \\
\text { citizen and user involve- } \\
\text { ment, looking outwards } \\
\text { and not focusing on our } \\
\text { internal administration " } \\
\text { (Interview 17) }\end{array}$ & $\begin{array}{l}\text { "citizen engagement is } \\
\text { on the political agenda } \\
\text { and increasingly impor- } \\
\text { tant and we have in- } \\
\text { cluded this in the digital- } \\
\text { ization and try to focus } \\
\text { more on the citizen." (In- } \\
\text { terview 18) }\end{array}$ & $\begin{array}{l}\text { "the involvement of citi- } \\
\text { zens and companies should } \\
\text { partly ensure a better de- } \\
\text { velopment and implemen- } \\
\text { tation of new digital solu- } \\
\text { tions, partly help create di- } \\
\text { alog and closeness in the } \\
\text { municipality." (Hedensted, } \\
\text { strategy) }\end{array}$ \\
\hline
\end{tabular}

from the point of view of those who live it' [70]. The primary categories (value positions) are derived by theoretical argumentation, whereas an elaboration of the categories is obtained inductively through analysis of the empirical material, using techniques familiar from grounded theory [71] and content analysis [72]. The empirical investigation also serves to validate the theoretical work by demonstrating correspondence between theory and empirical data.

\section{Managerial value positions in Danish local government}

In this section, we validate the existence of the three value positions (where we expect to find most rivalry) in the discourse of managers and their strategy documents, identify some conflicts and contradictions between them, and examine how the managers prioritise them. We identified the three value positions in all the four different data sources (CEO, CIO, CSM, strategy) from the 10 Danish local authorities. Table 5 presents some typical statements from the various interviews characterizing their perceptions of aspects of the three value positions.

Quantitative content analysis (Section 6.1) establishes a bias towards administrative efficiency in the managerial discourse. Qualitative content analysis (Sections 6.2-4) elaborates the basic value position concepts and identifies tensions between them.

\subsection{Analysis overview}

In our analysis of interviews and strategy documents from 10 Danish local authorities, we identified 380 instances reflecting purpose or motivation for e-Government and associated them with value positions. Of 680 in vivo codes, 401 relate to administrative efficiency, 194 to service improvement and 85 
Table 6

Distribution of value position codes

\begin{tabular}{lccccc}
\hline & Municipal CIO & Municipal CEO & Citizen service manager & IT strategy document & Total \\
\hline Administrative efficiency & $71 \%(59)$ & $60 \%(64)$ & $49 \%(39)$ & $49 \%(55)$ & $57 \%(217)$ \\
Service improvement & $19 \%(16)$ & $31 \%(33)$ & $33 \%(26)$ & $36 \%(40)$ & $30 \%(115)$ \\
Citizen engagement & $10 \%(8)$ & $8 \%(9)$ & $18 \%(14)$ & $15 \%(17)$ & $13 \%(48)$ \\
Total & $(83)$ & $(106)$ & $(79)$ & $(112)$ & $(380)$ \\
\hline
\end{tabular}

to citizen engagement (see Tables 3-5 for a conceptual synthesis of these). The administrative efficiency value position occupies most space in the managerial discourse of senior local authority officials in Denmark with $57 \%$ of the 380 identified instances (service improvement $30 \%$, citizen engagement $13 \%$ ). The citizen engagement value position is not prominent. Table 6 summarizes the coding frequencies.

Administrative efficiency is the dominant value position, whatever the formal role of the manager even where that role is to provide service to citizens. IT managers (CIO's) show the strongest association with administrative efficiency, even though they might be assumed to understand the role of IT in supporting other positions. Our coding practice supports the identification of coherent statements in the interviews or strategy documents with multiple or overlapping value position codes. Service improvement overlaps 44\% (51/115) with administrative efficiency while citizen engagement overlaps 19\% (9/48). These overlaps additionally support the observation of a strong bias towards administrative efficiency.

\subsection{Administrative efficiency}

Danish local authority managers show an enduring concern for administrative efficiency through the implementation of IT. One exemplifying practice involves retrieving the targeted financial benefits of a new IT system from a department manager's budget when the system is implemented.

"It is part of decentralization and an approach to control [the financial benefits of IT]. You could say they [the department managers] lose the money in their first budgets." (Interview 14, CEO)

The municipal CEO acknowledges that the financial benefits of the IT system may not be realised, but efficiency gains are forced in any case:

"If they don't find it in the administrative personnel budgets then they may take them from other places in the administration.... that's actually just as good" (Interview 14, CEO)

The department manager is not allowed to reduce the level of service in order to make administrative rationalizations; however the municipal CEO trusts that the assignments of spending in the budget are followed, and does not check if it is actually the case:

"If the financial targets are not met through improved case handling in the Family and Employment department it must not affect kindergarten children ...... but we do not subsequently check it" (Interview 14, CEO)

Here a concern for efficiency through budget reduction supersedes the concern for the outcomes of the IT implementation. The CEO shows a concern for service levels - but not to the extent of monitoring them. A citizen service manager shows a similar concern for administrative efficiency:

"It's a dilemma - we want to rationalize as much as possible, but some limitations make it impossible...... the data protection act is a good example of that." (Interview 24, CSM) 
Table 7

Conceptualizations of administrative efficiency

\begin{tabular}{llll}
\hline - Administration downsizing & - Cost awareness & - Investment & - Return on investment (ROI) \\
- Administrative simplification & - Cost benefit & - LEAN & - Savings \\
- Benchmarks & - Cost-effectiveness & - Localized benefits & - Synergy \\
- Best and cheapest & - Economies of scale & - Management information & - Task reduction \\
- Bottom line & - Effectiveness & - Organizational downsizing & - Time optimization \\
- Budgets & - Efficiency & - Payback time & - Value for money \\
- Business case & - Employee retention and & - Payroll savings & - Welfare limit \\
- Business strategy & recruitment & - Profit & - Work optimization \\
- Business value & - Faster administration & - Rationalization & \\
- Cheaper services & - Financial benefit & - Reducing operating costs & \\
- Citizen self-service & - Financial challenges & - Releasing resources & \\
& - Income generation & - Resource management & \\
\hline
\end{tabular}

Here the manager experiences a foundational value (upholding the law for protecting the personal data of citizens) as a limitation in relation to a more important objective - administrative efficiency.

The rationalization concept used in the previous quotation is one of several common conceptualizations of administrative efficiency used by Danish local authority managers. Table 7 synthesizes 42 conceptualizations of administrative efficiency in the 10 Danish local authorities based on 401 in vivo codes for this value position. The table reflects the inclusive use of the term efficiency (by both managers and researchers); it is used as a portmanteau term to catch many concerns related to financial measures, rather than to refer to a narrow relationship between input and output.

\subsection{Service improvement}

The IT strategy documents of the local authorities make many references to service improvement for citizens and businesses

"The local authority should ensure that the citizen does not have to provide his or her personal information more than once" (Næstved, strategy)

and it is clearly on the agenda of local managers:

"The next step is that information should be pushed out to citizens, so they know for example when they need a new health insurance card, or their doctor is out of action or retired.....then we can push out a new card... your driver's license is about to expire so you should apply for a new one... so we can be proactive with our citizens' (Interview 18, CSM)

Strategic statements of service improvement can overlap with efficiency logics - effective identity management through IT is a benefit for both municipality and citizen. Thus, dual concern often blurs the service improvement value. Managers are interested in take-up of their on-line services both because they think it is more convenient for citizens, and because it promotes administrative efficiency. Instead of being served by the municipality, citizens can serve themselves. Even citizen service managers bind the values together:

"Our aim is that citizens ... get help in the best possible way... while of course we prefer that citizens self-serve online according to their capabilities, because it helps us.... because we are busy enough as it is, so it would really help us if they did it more than they do now." (Interview 21, CSM)

This blurring of the service ideal is so prevalent that one citizen service manager takes the role of champion for the service improvement potential of self-service: 
Table 8

Conceptualizations of service improvement

\begin{tabular}{llll}
\hline - Adoption by citizens & - Ease of use & - Open 24.7 & - Solution consistency \\
- Greater availability & - Faster service & - Outside view & - Focus on citizen target groups \\
- Benefits for citizens & - Good service & - Proactive service & - Time space independence \\
- Better service & - Helping citizens & - Quality improvement & - Transparency \\
- Better solutions & - Increased service level & - Relevant and current & - Usability \\
- Centralized services & - Integrated service & information & - Value for citizens and companies \\
- Citizen satisfaction & - Modern & - Self service & - Welfare technology \\
- Citizen-centred service & - New access channels & - Service close to the citizen & \\
- Citizens' requirements & - One stop entry & - Service development & \\
\hline
\end{tabular}

"I am a spokesperson for making [self service] a service improvement.......it actually has to be done in the way that our citizens think that this is what they want." (Interview 24, CSM)

Repeated examples from both managers and IT strategy documents link service improvement with administrative efficiency:

"We focus on how the citizen get better access to do more things themselves. This is because it is easier for us and because we are under financial pressure..." (Interview 5, CEO)

The concept of self-service used by the local authority managers is one of several common conceptualizations of service improvement. Table 8 synthesizes 33 conceptualizations of service improvement based on 194 in vivo codes.

\subsection{Citizen engagement}

Citizen engagement is recognized as something that is necessary and unavoidable, but more as a future challenge than something that is currently a priority. Citizen involvement is, however part of a political agenda and must therefore be respected:

"Involvement of citizens is on the political agenda and is more and more present. We included it in the digitalization effort and try to focus more on citizens." (Interview 18, CSM)

However, democracy-focused digitalization efforts troubled local authorities:

"A number of authorities have tried digital "democracy-instruments" such as debate forums, project spaces, targeted sub-sites, etc. but with no great success. This may be due to lack of interest from citizens, but may just as well be because of problems with getting the message out. It's no longer sufficient to use the traditional channels such as the municipality's homepage, newspapers, public meetings, etc. to inform and engage citizens..." (Frederikshavn, strategy)

Good intentions are visible, especially in IT strategies:

"It is necessary to meet the citizens and the press where they are, which today means through digital channels used daily by large parts of the population... for example Google, Facebook, or the webpages of associations, schools, and kindergartens etc. ... information should target the individual citizen..." (Frederikshavn, strategy)

These intentions often remain at the level of espoused values, however, rather than values-in-action. Managers want to use IT to support local democracy - however, more pragmatic values, including the efficiency value, intervene: 
Table 9

Conceptualizations of citizen engagement

\begin{tabular}{llll}
\hline - Challenging citizens & - Competency development & - Expanding usage & - Reaching out to citizens \\
- Citizen and companies' & - Democratic participation & - Focus on citizens & - Relationship with citizens \\
capabilities & - Democratic rights & - Guidance for citizens & - Sense of ownership \\
- Citizen demands & - Dialog with citizens and & - Information accessibility & - Usefulness \\
- Collaboration with citizens & companies & - Involving users, citizens, & - Web 2.0 possibilities \\
- Community involvement & - Educating citizens and & and companies & \\
& companies & - Local democracy & \\
\hline
\end{tabular}

"Because we are a rural area and vulnerable, we [a group of municipalities in the region] wanted to collaborate and make something big in IT. We have to preserve jobs out here. Also, we wanted to make the IT area interesting to attract the necessary labour to our area.

[Interviewer] It was not to prepare for a municipal merger reform?

No, the exact opposite... It was to counteract it! ... it was intended to preserve local democracy... and then it was of course to improve our finances..." (Interview 23, CEO)

In this case, the group of four municipalities consolidated their IT departments into a single crossmunicipal unit with only one CIO. The intention was to preserve the independence of the collaborating municipalities whilst improving administrative efficiency in their use of IT. However, the initiative to preserve local democracy failed, and in the end, their IT re-organization served to facilitate the merger they were trying to avoid.

The concepts of local democracy and reaching out to citizens are a few of several common conceptualizations of citizen engagement used by the Danish local authority managers and documents. Table 9 synthesizes 22 conceptualizations of citizen engagement in the 10 Danish local authorities based on 85 in vivo codes for this value position.

In summary, both the qualitative and quantitative content analyses of Danish local authority managers' value positions show a heavy bias towards administrative efficiency over service improvement, with citizen engagement more evident in formalized intent than in action.

\section{Discussion - Rival value positions and the efficiency imperative}

We respond to Bannister and Connolly's [17] call for research into public values by synthesizing research findings from the public administration value literature [26|28-30] and from e-Government value studies [15 16]. We base the synthesis on previous work of Snellen [33] and Dobel [28]. We provide the first study of managerial value positions for e-Government that incorporates both a developed theoretical justification (through analysis of public administration traditions), and empirical validation with a targeted group of research subjects. The theoretical background is important to connect the value study to normative trends in the research discourse, whereas the empirical validation anchors theoretical discussions in the real concerns of managers. We understand value positions as significant ends-in-view [25] and incorporate public administration understandings of rivalries in the value landscape. Values do not necessarily provide a harmonious background for action but may be competing and contentious [27|31]. We identify contentious (value positions) and non-contentious (foundational) values - thus major rivalries between value positions. The resulting model synthesises much of the previous literature and expands Persson and Goldkuhl's [15] theoretical argument whilst providing a more solid empirical foundation than Bannister and Connolly [17]. 
The empirical evidence presented in the previous section suggests that senior public administrators responsible for local e-Government in Denmark resolve rivalry between value positions by prioritising administrative efficiency. In this sense, they are motivated by the efficiency imperative. Not only does the efficiency value predominate in their thinking about e-Government, but also it is woven into their values-in-action, often re-appearing when they discuss service improvement and citizen engagement. In empirical instances where values are mentioned together, the efficiency position often wins over other positions, which are subsumed by the efficiency argument, or sometimes even invalidated by it. A more balanced distribution of values occurs in strategy documents - the espoused values of the managers (closely matched by values in action of citizen service managers) - but even here, the efficiency value position is dominant. This efficiency dominance implies that managers primarily view IT as automation - as a productivity, or labour substitution tool [73]. The consequences of the efficiency imperative can be, paradoxically, rather ineffective e-Government. Drucker reminds us that 'there is surely nothing quite so useless as doing with great efficiency what should not be done at all' [74]. A focus on shortterm cost saving can risk undermining the foundational value of IT as the primary infrastructure for modern public administration. This focus implies that upgrades of hardware and software, integration of IT services, development of net and mobile architectures, data integrity and security and many other foundational issues may be neglected. IT investments (even in labour saving tools) do not automatically lead to better productivity unless internal reforms accompany them, so the basic premise that IT delivers cost reductions is possibly flawed. E-services that are devised to promote administrational goals may be unattractive to the public and suffer poor take-up. Efficiency (when viewed as cost-saving) and service improvement are rival value positions (the easiest way to cut costs is to reduce service levels), so the introduction of technologies that achieve both purposes is not simple. Devising effective policy that is also implementable may become easier through technology-mediated citizen engagement. Lack of citizen engagement can make it difficult to implement effective services that are meaningful and desirable for citizens; furthermore the longer term legitimacy of government risks being undermined if managers do not pay sufficient attention to supporting democratic involvement. Finally it could be mentioned that the cognitive framing of ICT is narrow in relation to its many possibilities.

\section{Conclusions}

In this article, we posed the question: how can rival value positions of public managers (understood as overall purpose, motivation and common goals for e-Government initiatives) be summarized? In response, we investigated the public administration literature, identified major value traditions and synthesised a model of competing e-Government value positions. Foundational values are a central concern; although they do not much motivate e-Government projects, they cannot be safely ignored. We identify three value positions of e-Government as administrative efficiency, service improvement, and citizen engagement. We find that the three positions figure significantly in the discourse of Danish local authority managers and elaborate them through empirical analysis as a further contribution. Though the data is Danish, the theoretical argument comes from many sources, so we expect that the descriptive model can be safely generalised; at least to other democracies. We further asked: how do public sector managers prioritise competing value positions when they introduce new information and communication technologies (ICT)? Our analysis of the empirical evidence indicates that Danish local authority managers resolve value position rivalry by prioritising administrative efficiency. Their commitment to service improvement is subsidiary, and citizen engagement is recognised as important, but not prioritised. We argue that this value prioritisation constitutes an efficiency imperative - our primary empirical 
finding. It is hard to implement e-Government projects in Denmark unless efficiency is a major concern. The contributions of the article are to:

- Anchor e-Government values in a taxonomy of e-Government (Section 4) and previous work in the field (Section 2);

- Provide a model of e-Government value positions which synthesizes previous accounts (Section 4);

- Demonstrate both generally agreed (foundational) and potentially competing (rival value positions) sets of values (Section 4);

- Show how the focus of e-Government value studies may be re-directed toward value position rivalry;

- Provide an empirical validation linked to a particular population of salient administrators (Section 6);

- Demonstrate a common bias in the prioritising of competing values towards administrative efficiency (Section 6);

- Argue that, when related to public administration literature traditions, this bias is neither natural or inevitable but contentious, and not necessarily healthy (Section 7).

A minimum standard for future value studies might include a dual focus on theoretical and empirical justification, and consideration of value rivalry. Concerning limitations of the study, we accept that the value landscape in the public administration literature is much larger and more complex than our adaptation of it here. Future studies may complement or present differing adaptations of this landscape. Our qualitative research methodology is limited as a validation tool, and the subject could benefit from quantitative applications. We also accept that other research subjects (for example street-level administrators or politicians) might prioritise value positions differently. We expect that political and contextual considerations play a substantial role in prioritising value positions and do not intend our Danish efficiency imperative to be generalised to other situations without further studies. Future research may focus on understanding relationships between e-Government values, the role of the value sponsor, and integrating value perspectives with the decision making of managers, for example in project portfolio management.

Since efficiency is a major concern of e-Government research, a one-dimensional view of managers as budget keepers is quite common, and a productivity tool view of IT widely adopted. Thus, readers may find the efficiency imperative the natural focus of e-Government - therefore unproblematic. These readers might consider whether they themselves are trapped in a view of the public sector dominated by New Public Management thinking. The efficiency imperative is clearly considered controversial by other schools of public administration researchers. Neither do the managers involved agree with their own values-in-action; when the results of the study were fed back to them in workshops they responded that, even though they were not surprised by the prioritisation reported here, they ought to prioritise the value positions equally whilst simultaneously preserving a focus on foundational values. This last report illustrates a further advantage of value position studies - they serve to expose and prioritise major objectives (ends-in-view) for e-Government. A normative discussion of the field's value positions, and how they should be balanced or prioritised, can serve as a complimentary vehicle for expressing the overall direction both of the field, both for researchers and practitioners.

\section{Conflict of interest}

No conflicts of interest are registered. 


\section{Acknowledgement}

This research was supported by the DISIMIT project funded by the Danish Research Council.

\section{Glossary}

Value: Intrinsic worth

Values: Assessments of intrinsic worth, leading to prioritizations of desirable behaviours, objectives and courses of action for the future

Value position: Internally coherent and synergistic group of values

Value tradition: The values embodied in a (historical) school of PA literature

$y$ values: The values identified in tradition $\mathrm{y}$

Public administration values - Those found in PA literature or practice whether stated or inferred

Public value (management): Refers to the work of Moore and related studies

Value landscape: The overall picture of available values - theoretical or empirical

Value categorization: A formal scheme proposed in the literature

Value grouping: Informal categories not based on theory explained in Table 3

\section{References}

[1] Gauld R, Goldfinch S. Dangerous Enthusiasms: E-government, Computer Failure and System Development, Otago University Press, Dunedin, New Zealand, 2006.

[2] Grimsley M, Meehan A. e-Government information systems: Evaluation-led design for public value and client trust. European Journal of Information Systems. 2007; 16: 134-148.

[3] Irani Z, Love PED, Elliman T, Jones S, Themistocleous M. Evaluating e-government: Learning from the experiences of two UK local authorities. Information Systems Journal. 2005; 15: 61-82.

[4] Bannister F. Dismantling the silos: extracting new value from IT investments in public administration. Information Systems Journal. 2001; 11: 65-84.

[5] Otjacques B, Hitzelberger P, Feltz F. Interoperability of e-government information systems: Issues of identification and data sharing. Journal of Management Information Systems. 2007; 23: 29-51.

[6] Meso P, Musa P, Straub D, Mbarika V. Information infrastructure, governance, and socio-economic development in developing countries. European Journal of Information Systems. 2009; 18: 52-65.

[7] Pan G, Pan SL, Newman M, Flynn D. Escalation and de-escalation of commitment: A commitment transformation analysis of an e-government project. Information Systems Journal. 2006; 16: 3-21.

[8] Carter L, Belanger F. The utilization of e-government services: citizen trust, innovation and acceptance factors. Information Systems Journal. 2005; 15: 5-25.

[9] Irani A, Elliman T, Jackson P, Electronic transformation of government in the U.K.: A research agenda. European Journal of Information Systems. 2007; 16: 327-335.

[10] Tan CW, Pan SL. Managing e-transformation in the public sector: an e-government study of the Inland Revenue Authority of Singapore (IRAS). European Journal of Information Systems. 2003; 12: 269-281.

[11] Kumar R, Best ML, Impact and Sustainability of E-Government Services in Developing Countries: Lessons Learned from Tamil Nadu, India. Information Society. 2006; 22: 1.

[12] Altameem T, Zairi M, Alshawi S. Critical success factors of E-government: A proposed model for E-government implementation, in: Innovations in Information Technology, IEEE, Dubai, 2006, pp. 501-505.

[13] Luk SCY. The impact of leadership and stakeholders on the success/failure of e-government service: Using the case study of e-stamping service in Hong Kong. Government Information Quarterly. 2009; 26: 594-604.

[14] Garson GD. Public information technology and e-governance: Managing the virtual state, Jones and Bartlett Publishers, Raleigh, N.C., 2006, xvi, p. 541.

[15] Persson A, Goldkuhl G. Government Value Paradigms - Bureaucracy, New Public Management, and E-Government. Communications of the AIS. 2010; 27: 45-62.

[16] Bannister F. Citizen centricity: A model of IS value in public administration. Electronic Journal of Information Systems Evaluation. 2002; 5. 
[17] Bannister F, Connolly R. ICT, public values and transformative government: A framework and programme for research. Government Information Quarterly. (2014).

[18] Esteves J, Joseph RC. A comprehensive framework for the assessment of eGovernment projects. Government Information Quarterly. 2008; 25: 118-132.

[19] Sikula AF. The values and value systems of governmental executives. Public Personnel Management. 1973; 2: 16-17.

[20] Moore MH. Public value as the focus of strategy. Australian Journal of Public Administration. 1994; 53: 296-303.

[21] Moore MH. Creating public value: Strategic management in government, Harvard Univ Press, Harvard, 1995.

[22] Castelnovo W, Simonetta M. The evaluation of e-Government projects for small local government organisation. Electronic Journal of e-Government. 2007; 5.

[23] Scott M, DeLone WH, Golden W. Understanding Net Benefits: A citizen-based perspective on egovernment success, in: Thirtieth International Conference on Information Systems (ICIS 2009), AIS, Phoenix, Arizona, 2009, pp. 1-11.

[24] Bonina CM, Cordella A. Public sector reforms and the notion of 'Public Value': Implications for eGovernment Deployment, in: AMCIS 2009 Proceedings, AIS, San Francisco, CA, 2009, pp. 1-8.

[25] Dewey J. Theory of valuation. International Encyclopedia of Unified Science. 1939; 2: 1-66.

[26] Jørgensen TB, Bozeman B. Public Values. Administration \& Society. 2007; 39: 354-381.

[27] Rutgers MR. Sorting out public values? On the contingency of value classification in public administration. Administrative Theory \& Praxis. 2008; 30: 92-113.

[28] Dobel JP. Public Management as Ethics, in: The Oxford Handbook of Public Management, E. Ferlie, L.E. Lynn and C. Pollitt, eds, Oxford University Press, Oxford, 2007.

[29] Hood C. A public management for all seasons? Public Administration. 1991; 69: 3-19.

[30] Van Wart M. Changing public sector values, Routledge, New York, 1998.

[31] Van Der Wal Z, van Hout ETJ. Is public value pluralism paramount? The intrinsic multiplicity and hybridity of public values. Intl Journal of Public Administration. 2009; 32: 220-231.

[32] Schein EH. Organizational culture and leadership, John Wiley \& Sons New York, 2004.

[33] Snellen I. E-government; a Challenge for Public Management, in: The Oxford Handbook of Public Management, E. Ferlie, L. Lynn and C. Pollitt, eds, Oxford University Press, Oxford, 2005.

[34] Orlikowski WJ, Gash DC. Technological Frames: Making Sense of IT in Organizations. ACM Transactions on Information Systems. 1994; 12: 174-207.

[35] Chircu AM. E-government evaluation: Towards a multidimensional framework. Electronic Government, an International Journal. 2008; 5: 345-363.

[36] Foley P. The Real Benefits, Beneficiaries and Value of E-Government. Public Money \& Management. 2005; $25: 4$.

[37] Grimsley M, Meehan A. Attaining Social Value from Electronic Government. Electronic Journal of e-Government. 2008; 6: 31-42.

[38] Kim S, Kim D. South Korean public officials' perceptions of values, failure, and consequences of failure in e-government leadership. Public Performance \& Management Review. 2003; 26: 360-375.

[39] Liu JW, Derzsi Z, Raus M, Kipp A. eGovernment Project Evaluation: An Integrated Framework. Electronic Government, Proceedings. 2008; 5184: 85-97.

[40] Prakash N, Jaiswal M, Gulla U. A conceptual framework for measuring public value of enterprise applications. Electronic Government, an International Journal. 2009; 6: 307-326.

[41] Steyaert JC. Measuring the performance of electronic government services. Information \& Management. 2004; 41: 369.

[42] Yu C-C. A Value-Based Strategic Management Process for e-Government Strategy Planning and Performance Control, in: ICEGOV 2007 (1st International Conference on Theory and Practice of Electronic Governance), T. Janowski and T.A. Pardo, eds, ACM Press, Macao, 2007, pp. 169-178.

[43] Cordella A, Bonina CM. A public value perspective for ICT enabled public sector reforms: A theoretical reflection. Government Information Quarterly. 2012; 29: 512-520.

[44] Kjær U, Hjelmar U, Olsen AL. Municipal amalgamations and the democratic functioning of local councils: The case of the Danish 2007 Structural Reform. Local Government Studies. 2010; 36: 569-585.

[45] Weber M. The theory of social and economic organization, Free Press, New York, 1947.

[46] Layne K, Lee JW. Developing fully functional E-government: A four stage model. Government Information Quarterly. 2001; 18: 122-136.

[47] Rose J, Persson JS. E-government value priorities of Danish local authority managers, in: IT Management in Local Government: the DISIMIT Project, J. Rose, J.S. Persson, P. Krømmergaard and P.A. Nielssen, eds, Software Innovation, Aalborg, 2012, pp. 27-56.

[48] Frederickson HG. Comparing the reinventing government movement with the new public administration. Public Administration Review. 1996; 56: 263-270.

[49] Goodsell CT. The case for bureaucracy: A public administration polemic, Chatham House Publishers, 2004.

[50] Denhardt RB, Denhardt JV. The new public service: Serving rather than steering, Sharpe, New York, 2007. 
[51] Denhardt RB, Denhardt JV. The new public service: Serving rather than steering. Public Administration Review. 2000; 60: 549-559.

[52] Gore A. Creating a government that works better and costs less: Department of Energy. Accompanying report of the national performance review, National Performance Review, Washington, DC (United States), 1993.

[53] Boston J. The theoretical underpinnings of public sector restructuring in New Zealand. Reshaping the State, Oxford University Press, Auckland. 1991; 1-26.

[54] Osborne D, Plastrik P. Banishing Bureaucracy: The Five Strategies for Reinventing Government, Addison-Wesley, Reading, MA, 1997.

[55] Osborne D, Gaebler T. Reinventing government: How the entrepreneurial spirit is transforming the public sector, Plume, New York, 1992.

[56] Moe RC. The "reinventing government" exercise: Misinterpreting the problem, misjudging the consequences. Public Administration Review. 1994; 54: 111-122.

[57] DeLeon L, Denhardt RB. The political theory of reinvention. Public Administration Review. 2000; 60: 89-97.

[58] Du Gay P. In praise of bureaucracy: Weber, organization, ethics, Sage Publications Ltd, 2000.

[59] Osbourne S. The New Public Governance? Public Management Review. 2006; 8: 377-387.

[60] Miller T. The operation of democratic institutions. Public Administration Review. 1989; 49: 511-521.

[61] Frederickson HG. Toward a theory of the public for public administration. Administration \& Society. 1991; $22: 395$.

[62] Rose J, Sæbø Ø. Designing Deliberation Systems. The Information Society. 2010; 26: 228-240.

[63] Sæbø Ø, Rose J, Molka-Danielsen J. eParticipation: Designing and Managing Political Discussion Forums. Social Science Computer Review. 2010; 28: 403-426.

[64] Jansen H. The Logic of Qualitative Survey Research and its Position in the Field of Social Research Methods. Forum: Qualitative Social Research. 2010; 11. http://www.qualitative-research.net/index.php/fqs/article/view/1450/2946.

[65] Jenkins AM. Research Methodologies and MIS Research, in: Research Methods in Information Systems, E. Mumford, ed., Elsevier Science Publishers B.V., Amsterdam, Holland, 1985, pp. 103-117.

[66] Wilkinson S. Focus group research, in: Qualitative Research: Theory, Method and Practice, D. Silverman, ed., Sage, London, 1997, pp. 177-199.

[67] Fielding NG, Lee RM. Computer analysis and qualitative research, SAGE Publications, London, 1998.

[68] Merton RK. Social Theory and Social Structure, Free Press of Glencoe, New York, 1957.

[69] Gregor S. The nature of theory in information systems. MIS Quarterly. 2006; 30: 611-642.

[70] Schwandt TA. Constructivist, interpretivist approaches to human inquiry, in: Handbook of qualitative research, N.K. Denzin and Y.S. Lincoln, eds, Sage, Thousand Oaks, CA, 1994, pp. 118-137.

[71] Strauss A, Corbin J. Grounded Theory in Practice, Sage, London, 1997.

[72] Krippendorff K. Content Analysis Sage, Thousand Oaks, 2004.

[73] Orlikowski WJ, Iacono CS. Desperately seeking the 'IT' in IT research: A call to theorizing the IT artifact. Information Systems Research. 2001; 12: 121-134.

[74] Drucker P. On the Profession of Management, Harvard Business School, Boston, 1963. 


\section{Appendix 1: List of kommunes and interviews}

$\begin{array}{llll}\text { Aabenraa kommune } & \text { Favrskov kommune } & \text { Hedensted kommune } & \text { Tønder kommune } \\ \text { Aalborg kommune } & \text { Frederikshavn kommune } & \text { Næstved kommune } & \\ \text { Aarhus kommune } & \text { Gentofte kommune } & \text { Odense kommune } & \end{array}$

\begin{tabular}{|c|c|c|c|}
\hline Interview no. & $\begin{array}{l}\text { Kommune } \\
\text { (randomised no.) }\end{array}$ & Interviewee (role) & Date \\
\hline 1 & 1 & Municipal CIO & May 25, 2009 \\
\hline 2 & 1 & Municipal CEO & May 25, 2009 \\
\hline 3 & 1 & Citizen service manager & May 25, 2009 \\
\hline 4 & 2 & Municipal CIO & May 25, 2009 \\
\hline 5 & 2 & Municipal CEO & May 25, 2009 \\
\hline 6 & 2 & Citizen service manager & May 25, 2009 \\
\hline 7 & 3 & Municipal CIO & May 26, 2009 \\
\hline 8 & 3 & Municipal CEO & May 26, 2009 \\
\hline 9 & 3 & Citizen service manager & May 26, 2009 \\
\hline 10 & 4 & Municipal CIO & May 28, 2009 \\
\hline 11 & 4 & Municipal CEO & May 28, 2009 \\
\hline 12 & 4 & Citizen service manager & May 28, 2009 \\
\hline 13 & 5 & Municipal CIO & June 3, 2009 \\
\hline 14 & 5 & Municipal CEO & June 3, 2009 \\
\hline 15 & 5 & Citizen service manager & June 3, 2009 \\
\hline 16 & 6 & Municipal CIO & June 4, 2009 \\
\hline 17 & 6 & Municipal CEO & June 4, 2009 \\
\hline 18 & 6 & Citizen service manager & June 4, 2009 \\
\hline 19 & 7 & Municipal CIO & June 9, 2009 \\
\hline 20 & 7 & Municipal CEO & June 9, 2009 \\
\hline 21 & 7 & Citizen service manager & June 9, 2009 \\
\hline 22 & 8 & Municipal CIO & June 10, 2009 \\
\hline 23 & 8 & Municipal CEO & June 10, 2009 \\
\hline 24 & 8 & Citizen service manager & June 10, 2009 \\
\hline 25 & 9 & Municipal CIO & June 11, 2009 \\
\hline 26 & 9 & Municipal CEO & June 11, 2009 \\
\hline 27 & 9 & Citizen service manager & June 11, 2009 \\
\hline 28 & 10 & Municipal CIO & June 25, 2009 \\
\hline 29 & 10 & Municipal CEO & June 25, 2009 \\
\hline 30 & 10 & Citizen service manager & June 25, 2009 \\
\hline
\end{tabular}

